\title{
In Vitro Selected Macrocyclic Peptides: Tools for Regulating the Conformational Freedom of Transmembrane Proteins
}

\author{
Christopher John Hipolito, ${ }^{*, \uparrow}$ 西尾洸 祐，菅＼cjkstart裕 明 \\ Christopher John Hipolito, ${ }^{*, \uparrow}$ Kosuke Nishio, and Hiroaki Suga \\ Department of Chemistry, Graduate School of Science, The University of Tokyo; \\ 7-3-1 Hongo, Bunkyo-ku, Tokyo 113-0033, Japan.
}

(Received August 11, 2015)

\begin{abstract}
Membrane proteins allow a cell to communicate with its environment by relaying a signal or transporting a molecule through the cell membrane. Elucidation of the three-dimensional structure of a membrane protein provides a greater understanding of its function and mechanisms. Ultimately, this knowledge will enlighten researchers on how these proteins can be regulated to elicit a desired cellular response, which could lead to novel therapeutic medicine. Unfortunately, the determination of the high-resolution crystal structures of transmembrane proteins remains a challenge due to their poor solubility and high conformational flexibility. Additives and cocrystallization ligands are being used to address these problems. In vitro selected macrocyclic peptides have recently been successfully employed as cocrystallization ligands. Although originally intended as inhibitors and drug lead molecules, in vitro selected macrocyclic peptides are now showing that their pharmacodynamic properties also allow them to serve as excellent cocrystallization ligands. Structures for macrocyclic peptide-bound transporters, the multidrug and toxic compound extrusion family transporter from Pyrococcus furiosus (PfMATE) and the ABC transporter subfamily B member 1 from Cyanidioschyzon meraloe (CmABCB1), have been elucidated using X-ray crystallography. The cocrystal structures reveal that the macrocyclic peptides improve crystallization by binding in a similar manner as a small molecule or a biologic. The PfMATE-binding macrocyclic peptides MaD3S and MaD5 bind to the surfaces buried in the center channel of the transporters. Although both transporters possess a center channel and substrate-binding pocket, the CmABCB1-binding macrocyclic peptide, aCAP, binds to the outer surface of the transporter in a similar manner to a biologic.
\end{abstract}

Key words - macrocyclic peptide; in vitro selection; cocrystallization

\section{1. 擬天然ペプチドの試験管内選択}

天然物ペプチドはしばしば, その生理学的性質向 上のため特徵的な構造を有する。これらの天然物ぺ プチドは，リボソームによる翻訳か非リボソーム系 ペプチド合成酵素（non-ribosomal peptide synthetases； NRPS）のどちらかで合成される. NRPS の場合，1つの NRPS は一種類のペプチドの遺伝子 情報しか有さない。注目すべき天然物大環状ペプチ ドの 1 つ，サイクロスポリンは，1.6 MDaの NRPS によって合成される. サイクロスポリンは, 大環状骨格, 非タンパク質性アミノ酸, 主鎖アミド

東京大学大学院理学系研究科化学専攻（F113-0033 東 京都文京区本郷 7-3-1)

現所属: †筑波大学医学医療系生命医科学域癌シグナリ

ング（テ305-8075 茨城県つくば市天王台 1-1-1)

*e-mail: hipolito@md.tsukuba.ac.jp

本総説は, 日本薬学会第 135 年会シンポジウムS 37 で 発表した内容を中心に記述したものである.
結合の $N$-メチル化といつた構造を有する．大環状 骨格は, ペプチドを活性型の構造に固定化すること でその活性を向上させる。 また，非タンパク質性ア ミノ酸やアミド結合の $N$-メチル化は可能な水素結 合の数を減らし，細胞膜透過性向上に寄与する。 そ のため, このような特徵的な構造はドラッグスク リーニングのためのペプチドライブラリの生化学的 な構築で非常に重要である. カス夕ム特殊ペプチド 合成のためには，NRPS を構成する一連の酵素群を カスタム改変やドメイン交換する必要があるが, 現 状では酵素活性の低下等の技術的な限界があり， 様々なカスタム特殊ペプチドの生産はいまだ達成さ れていない. したがって, NRPS の改変やドメイン 交換による特殊ペプチドライブラリ構築への応用に は，まだ多くの時間と技術的な進歩を必要するのが 現状である。

標準的な翻訳系では，ペプチドの配列情報は，合 
成産物であるぺプチドとは直接結合していない mRNA に記録されており交換可能である.1つの リボソームは多種多様な配列, 長さの標準ペプチド を作り出すことができ，ペプチドの多様性は mRNA のみにより制限される。標準的な翻訳系に より縮重したペプチドライブラリを構築することが 可能だが，それらのペプチドはタンパク質性の 20 種類のアミノ酸からなる直鎖状のペプチドであるこ とに留意しなければならない，それらのペプチドの 多くは，ジスルフィド結合を分子内に有することで 全体構造の自由度を制限し, 一定の構造に安定して いるが，ジスルフィド結合は例えば腫瘍細胞内など 生体内環境下で還元され易い。このような次第では あるが，翻訳系に少し手を加えることで，薬剤シー ズ探索としての魅力的な大環状ペプチドライブラリ を構築する方法が提唱されている. ${ }^{1)}$

菅らは，大環状骨格を有する特殊ペプチドを合成 する基盤技術を開発した. ${ }^{2}$ 標準的な翻訳系を改変 することで，彼らはコドン表の一部をタンパク質性 アミノ酸から非タンパク質性アミノ酸に割り当て直 すことを成し遂げた。それにより，リボソームに よって合成されるぺプチドに，一般的なコドン表で 定義されるアミノ酸以外の新しい化学的な機能を導 入することを可能にした. 菅らの基盤技術の最重要 点は, フレキシザイムと命名された試験管内分子進 化法で獲得されたリボザイムの利用である。フレキ シザイムは，化学的に活性化されたほぼどんな非夕 ンパク質性アミノ酸もアンチコドンによらずどんな tRNA へ付加することができる。再構成翻訳系で は，特定のコドンに関連する天然の構成成分を除 き，そのコドンに対応するアンチコドンの tRNA に非タンパク質性アミノ酸を付加したものを加えカ スタムした翻訳系を構成できる。

アミノアシル tRNA 合成酵素 (aminoacyl-tRNA synthetase; ARS） と比べフレキシザイムでの tRNA のアミノアシル化では, 内因性アミノ酸のコ ンタミネーションやアミノアシル化されるアミノ酸 の制限といつた問題を回避できる。このコドンの再 割り当ては一般的に，遺伝暗号リプログラミングと 呼ばれ, ${ }^{3)}$ このフレキシザイムによる遺伝暗号リプ ログラミングを施した再構成翻訳系は, flexible in vitro translation（FIT）システムと呼ばれる. ${ }^{4)}$ FIT システムは，ペプチドの大環状化のための官能基を
翻訳ペプチド合成開始ステップをリプログラミング するのに最もよく使用されるが，使用範囲はこの限 りではない.5)

生理活性大環状ペプチドの同定には，ペプチドと それをコードする遺伝情報を結びつける必要があ る．翻訳ペプチドとそれをコードする mRNA を結 合させる方法には，ファージディスプレイ6)やリボ ソームディスプレイ, ${ }^{7)}$ mRNA ディスプレイ ${ }^{8,9)}$ と いつた様々なディスプレイ法が存在する，random non-standard peptide integrated discovery (RaPID) システムは mRNA ディスプレイを用い，FIT シス テムによって合成されたペプチドとそれをコードす る mRNA をピューロマイシンリンカーを介し結合 する（Fig. 1). ${ }^{2}$ そして mRNA を結合された大環 状ペプチドは，興味対象のタンパク質に対し結合力 によってスクリーニングされる。しばしば，標的夕 ンパク質に対し結合スクリーニングされた大環状ペ プチドは，そのタンパク質の機能を阻害する。この RaPID システムを用いて，菅らは E6AP, ${ }^{10)}$ AKT2, ${ }^{11)}$ Sirt2 ${ }^{12)}$ に対する阻害剤の開発に成功して いる。ささらに, Sirt2 とその大環状阻害ペプチド S2iL5 との共結晶構造も解かれている (Fig. 2).13) S2iL5 をスクリーニングする際に使われた大環状ぺ プチドライブラリでは，ペプチドが Sirt2 の触媒部 位に結合するように，触媒機構に基づく warhead としてトリフルオロアセチルリジンを各ペプチドに 含まれるようデザインされている，それに加え，

S2iL5 の独特な水分子が結合した大環状ペプチド骨 格が Sirt2 への結合力や選択性に重要であることが 明らかとなった。様々な新規フォールディングモ チーフは多様な結合を可能にし, 構造生物学ではこ の多様な結合様式が相互作用する膜タンパク質の結 晶構造解析に利点をもたらしている.

\section{2. 膜タンパク質の結晶化における問題点}

膜タンパク質は主な創薬ターゲットであるにもか かわらず，可溶性タンパク質に比べその構造情報が 不足している。この理由は, 膜タンパク質は X 線 結晶構造解析に必要な高品質の結晶の獲得が困難で あるためである．膜タンパク質の結晶化が困難な第 一の原因は，疎水性表面を多く含む膜タンパク質を 可溶化するために界面活性剂を使用しなければなら ないことである，界面活性剤なしでは膜タンパク質 は，凝集沈殿してしまう。この界面活性剂は，膜夕 


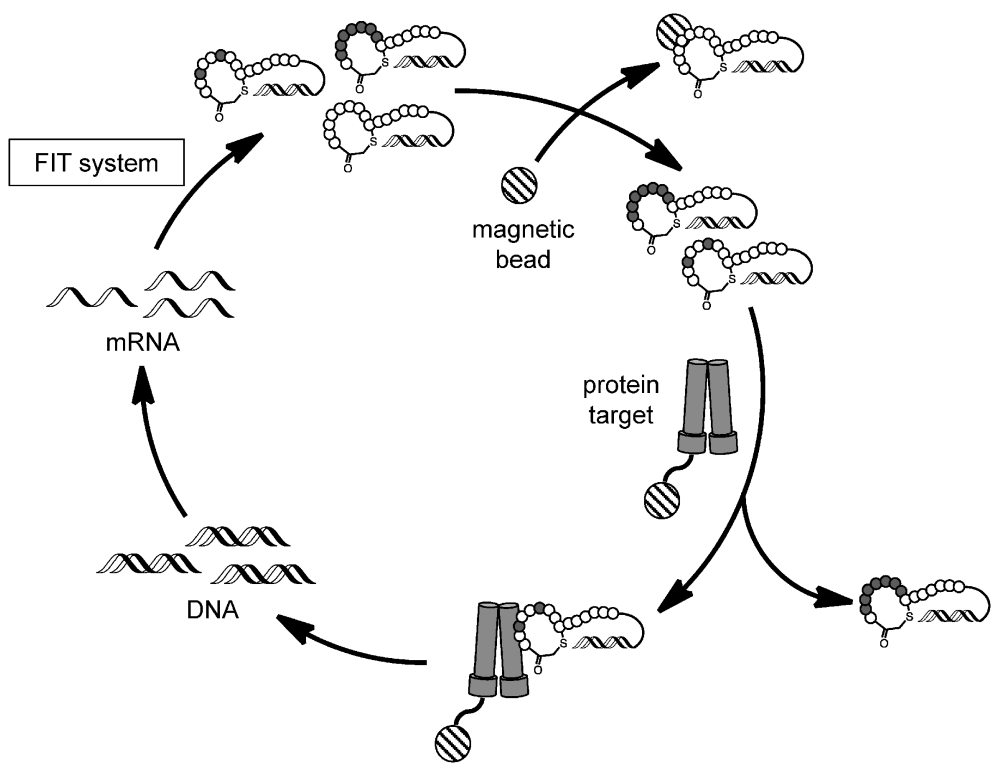

Fig. 1. The RaPID System

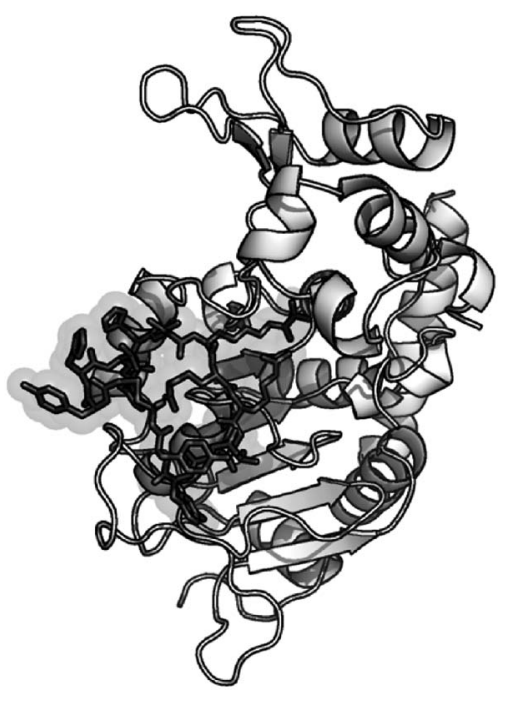

Fig. 2. Crystal Structure of the SIRT2:S2iL5 Complex SIRT2 is shown in cartoon representation. S2iL5 is shown in stick format.

ンパク質の膜貫通部位を囲うように可逆的なミセル を形成する. しかし，この可逆性ミセルの大きさは 均一ではなく, 特定の結晶形成に必要な疎水性表面 を覆い隠し，結晶の形成を阻害する，抗体を用いた 場合，可逆ミセル以上に親水性表面を拡張し，膜夕 ンパク質と抗体の複合体間の相互作用を促進す る. ${ }^{14)}$

膜タンパク質の結晶化が困難な第二の理由は，そ の構造自由度による．たとえあるタンパク質を精製 したとしても，エントロピーの負債により構造自由
度は結晶化に不利に働く，構造が固定化された単一 のタンパク質では，結晶格子を組み立てるためのエ ントロピーの負債がほとんどない。一方，rockerswitch 相互変換を伴うトランスポーターのような膜 タンパク質は非常に構造自由度が高く, 特定の構造 からなる結晶格子中にそれらを組み立てるのはより エントロピーの負債を伴い, 結晶格子の構築を完全 に妨げる. 結晶化リガンドは, タンパク質の構造を 特定のものに固定化することを補助する。これに関 しては，抗体を基にした結晶化リガンドは標的タン パク質の特定の構造の結晶化において有益な手法で あることが実証されている. ${ }^{15,16)}$ 後述の 2 つの研究 は，RaPID システムでスクリーニンングされた大 環状ペプチドが結晶化リガンドとして標的タンパク 質の構造を固定化し，その結晶化を容易にした好例 である.

\section{Pyrococcus furiosus 由来 multidrug and toxic} compound extrusion family transporter (PfMATE) の共結晶化

濡木らは，大環状ペプチドリガンドを頻繁に用い られる阻害剤としてではなく, 結晶化が困難なタン パク質の共結晶化の補助に用いることを試み た. ${ }^{17-19)}$ 彼らの挑戦的な結晶化の標的の 1 つとして PfMATE がある．PfMATE に対する RaPID シス テムによる大環状ペプチドリガンドスクリーニング の結果から，2つの主要なモチーフが同定された. 
A)

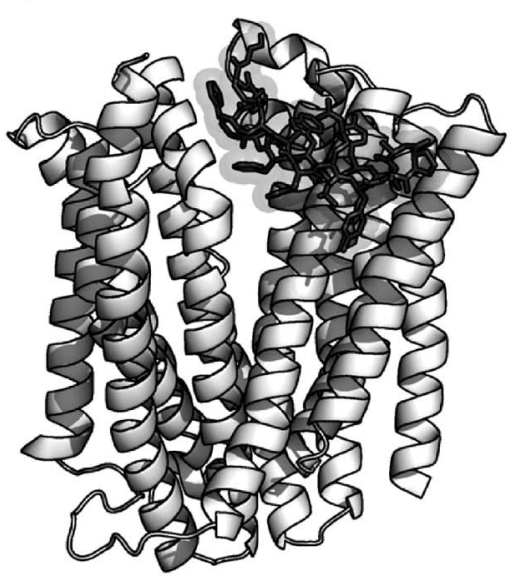

B)

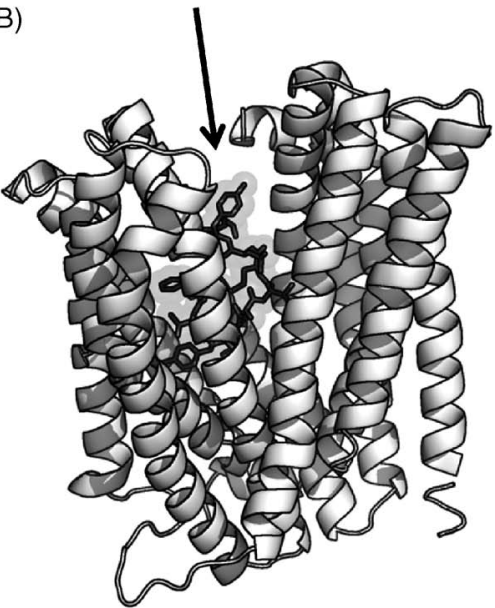

Fig. 3. PfMATE-binding Macrocyclic Peptides

A) The cocrystal structure of the PfMATE:MaL6 complex. B) The cocrystal structure of the PfMATE:MaD3S complex. The arrow indicates the location of the deeply buried MaD3S lariat-shaped peptide. PfMATE is shown in cartoon representation. MaL6 and MaD3S are shown in stick format.
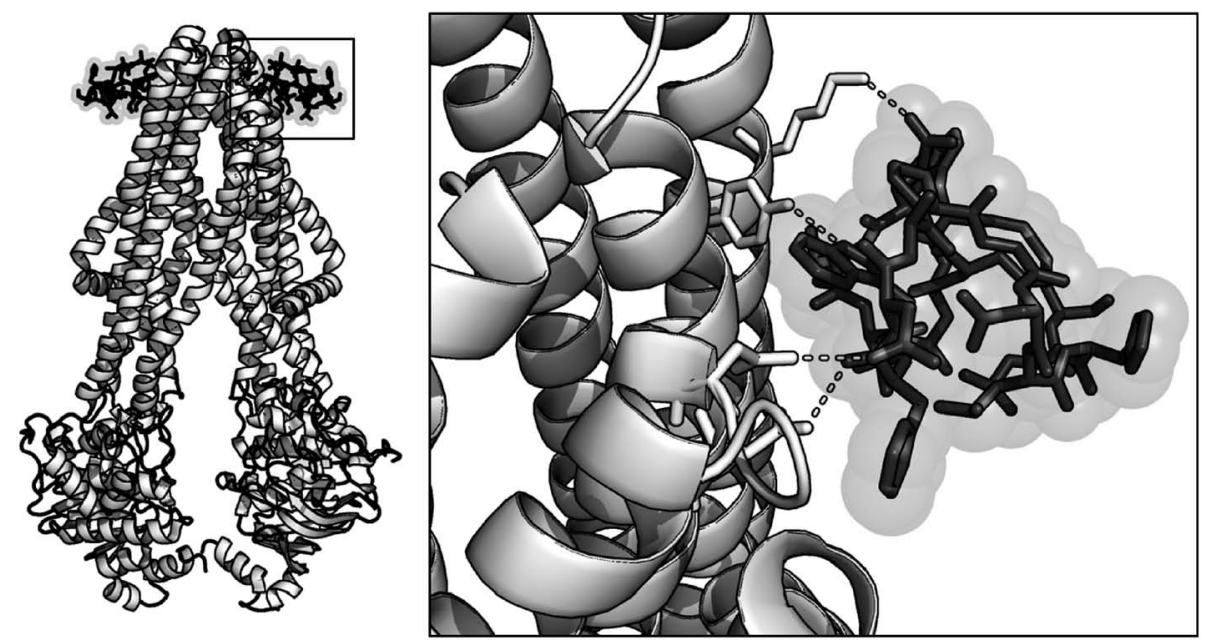

Fig. 4. Crystal Structure of the CmABCB1:aCAP

The inset box shows a close-up of the interactions between $\mathrm{CmABCB} 1$ and aCAP. CmABCB1 is shown in cartoon representation. aCAP molecules are shown in stick format.

その両方において，PfMATEの $\mathrm{N}$ 末端と C 末端の ローブ間，細胞外表面にある割れ目への結合が確認 された．MaL6 は 1 つ目のクラスのペプチドで, 17 残基のアミノ酸から構成される大環状ペプチドであ り, $\beta$ ヘアピン型構造を有し，その半分の面で PfMATE 表面の割れ目に結合しており，もう半面 はタンパク質との結合に関与していない $[$ Fig. 3 (A) ]。結合していない半面はPfMATE の構造を安 定化していないかもしれないが，結合に関与するぺ プチドのもう半面の構造に必要不可欠なのかもしれ ない。とにかく，MaL6 の PfMATEへの結合はお そらく, rocker-switch 相互変換に関連するタンパ ク質の動きを制限し，結合型及び非結合型の
PfMATE 高分解能結晶構造の決定を初めて可能に した.

2つ目のクラスは投げ輪構造を有する環状ペプチ ドで，PfMATE 表面の割れ目のより深くに結合し ている。ペプチド MaD5 と MaD3S は基質結合ポ ケット内深くに結合するのに対し一方，MaD8 は割 れ目のほぼ中心に結合している $\left[\right.$ Fig. 3(B) ]. ${ }^{19)}$ Rocker-switch 構造変化を妨げるのに加え, MaD5 と MaD3S の PfMATEへの結合は, $\mathrm{pH}$ 依存的に straight-to-kinked 相互変換することが知られる transmembrane helix 1（TM1）の構造自由度を制 限する。 TM1 の構造自由度の発見は, P26A 変異 体の作製と結晶化の着想も与えた。すなわち，へ 
リックス構造を崩すプロリンなしでは，TM1 はリ ガンドなしでも straight 型に固定化され，最高分解 能 $(2.1 \AA$ ) の結晶構造を与えた。投げ輪構造のペ プチドの結合様式ははじめ予想できなかったが，低 分子のように標的タンパク質のポケットに結合する ことが示された。

4. Cyanidioschyzon meraloe 由来 $\mathrm{ABC}$ transporter subfamily $B$ member 1（CmABCB1）の共結 晶化

PfMATE に対するスクリーニングから同定され た環状ペプチドは，低分子と同様に標的タンパク質 のポケットに結合することができるということが示 された。この知見から，小段らは Cyanidioschyzon meraloe 由来の P-glycoprotein 木モログ （CmABCB1）の中央チャネルに位置する基質結合 ポケットに結合し得る大環状ペプチドの探索を試み た. ${ }^{20)} \mathrm{RaPID}$ システムにより， CmABCB1 に結合 する大環状ペプチドを同定し，そのうちの 1 つ $\mathrm{aCAP}$ は $\mathrm{CmABCB} 1$ との共結晶化に成功した (Fig. 4).

aCAP の CmABCB1 への結合様式は, PfMATE 結合大環状ペプチドのそれとは大きく異なった。一 分子の $\mathrm{aCAP}$ が CmABCB1 のホモダイマーと結合 し， aCAP は両方のモノマーと結合していた。また さらには，aCAP は CmABCB1 の基質結合ポケッ トには結合していないが，膜貫通へリックスの細胞 外部位付近に結合していた，興味深いことに，その 結合様式は複数のタンパク質が相互作用し合うタン パク質間相互作用の結合様式と類似している.

$\mathrm{aCAP}$ は本来意図した場所に結合してはいない が，この新しい結合様式は，リガンド非結合型トラ ンスポーターの結晶構造の分解能 $2.7 \AA$ から, 大環 状ペプチド結合型トランスポーターの結晶構造の分 解能 $2.45 \AA$ へと結晶構造の分解能向上を助けた. 一方で，aCAP は強力な ATPase 阻害剂としても働 くことも分かった。 CmABCB1 の結晶構造と Sav1866 の結晶構造 21 から提唱されるトランスポー ターの作動機序は, 膜貫通ヘリックス TM1 と TM6 の細胞外末端が離れたり収束したりすることによる と考えられている. ${ }^{20)}$ 結晶構造によると, $\mathrm{aCAP}$ は，膜貫通へリックス TM2 と TM6 と水素結合を 形成しており，この 2 つのリックスを効率的に固 定化している，さらに，TM2 と TM6によって挟ま
れた TM1 は，aCAP が結合することで結果的に固 定化されてしまっている。 これらの膜貫通ヘリック スの動きとATPase 活性は密接に関連しており，特 殊ペプチドはこれらの膜貫通ヘリックス部位に結合 し，膜貫通ヘリックスの動きを阻害することで, ATPase の定常活性と基質刺激による活性の両方を 顕著に減少させることにつながつたと考えられる.

\section{5. 展望}

PfMATE と CmABCB1 の共結晶構造は，われわ れに大環状ペプチドの標的タンパク質への結合様式 に対する見識をもたらした。PfMATE 結合大環状 ペプチドの場合，大環状ペプチドは低分子のように 基質結合ポケットのくぼんだ表面に結合し，一方 CmABCB1 結合大環状ペプチドの場合， aCAP は タンパク質のようにふるまい，基質結合ポケットと いうょりはむしろ CmABCB1 の表面の平面に結合 した。これらの知見は，RaPID システムによる大 環状ペプチドリガンドのスクリーニングが，どのよ うに低分子様リガンド若しくはタンパク質様リガン ドの同定につながるかを説明している.

これまで，大環状ペプチドが標的タンパク質の特 定の構造を安定化することによる共結晶化の促進の みを示してきた。しかし，RaPID システムから同 定された大環状ぺプチドは，一例を除き主にタンパ ク質間相互作用の阻害剂として利用されてきた。 ${ }^{22)}$ 今のところ，大環状ペプチドが結晶格子形成促進に 十分な分子サイズであるという証拠はない。大環状 ペプチドを利用したタンパク質との共結晶化の分野 はまだ誕生したばかりであり，近い将来おそらくタ ンパク質の結晶を促進する大環状ペプチドはさらに 生み出されるであろう.

利益相反本稿で記述したペプチドは特許出願 されており（出願番号 PCT/JP2013/070779）， ペプ チドリーム株式会社（東京）にライセンス認可され ている.

\section{REFERENCES}

1) Passioura T., Katoh T., Goto Y., Suga H., Annu. Rev. Biochem., 83, 727-752 (2014).

2) Hipolito C. J., Suga H., Curr. Opin. Chem. Biol., 16, 196-203 (2012).

3) Forster A. C., Tan Z., Nalam M. N. L., Lin 
H., Qu H., Cornish V. W., Blacklow S. C., Proc. Natl. Acad. Sci. USA, 100, 6353-6357 (2003).

4) Goto Y., Katoh T., Suga H., Nat. Protoc., 6, 779-790 (2011).

5) Goto Y., Ohta A., Sako Y., Yamagishi Y., Murakami H., Suga H., ACS Chem. Biol., 3, 120-129 (2008).

6) Smith G. P., Science., 228, 1315-1317 (1985).

7) Hanes J., Plückthun A., Proc. Natl. Acad. Sci. USA, 94, 4937-4942 (1997).

8) Roberts R. W., Szostak J. W., Proc. Natl. Acad. Sci. USA, 94, 12297-12302 (1997).

9) Nemoto N., Miyamoto-Sato E., Husumi Y., Yanagawa H., FEBS Lett., 414, 405-408 (1997).

10) Yamagishi Y., Shoji I., Miyagawa S., Kawakami T., Katoh T., Goto Y., Suga H., Chem. Biol., 18, 1562-1570 (2011).

11) Hayashi Y., Morimoto J., Suga H., ACS Chem. Biol., 7, 607-613 (2012).

12) Morimoto J., Hayashi Y., Suga H., Angew. Chem. Int. Ed. Engl., 51, 3423-3427 (2012).

13) Yamagata K., Goto Y., Nishimasu H., Morimoto J., Ishitani R., Dohmae N., Takeda N., Nagai R., Komuro I., Suga H., Nureki O., Structure, 22, 345-352 (2014).

14) Hino T., Iwata S., Murata T., Curr. Opin. Struct. Biol., 23, 563-568 (2013).

15) Rasmussen S. G. F., Choi H. J., Fung J. J.,
Pardon E., Casarosa P., Chae P. S., Devree B. T., Rosenbaum D. M., Thian F. S., Kobilka T. S., Schnapp A., Konetzki I., Sunahara R. K, Gellman S. H., Pautsch A., Steyaert J., Weis W. I., Kobilka B. K., Nature, 469, 175180 (2011).

16) Ring A. M., Manglik A., Kruse A. C., Enos M. D., Weis W. I., Garcia K. C., Kobilka B. K., Nature, 502, 575-579 (2013).

17) Hipolito C. J., Tanaka Y., Katoh T., Nureki O., Suga H., Molecules, 18, 10514-10530 (2013).

18) Tanaka Y., Hipolito C. J., Maturana A. D., Ito K., Kuroda T., Higuchi T., Katoh T., Kato H. E., Hattori M., Kumazaki K., Tsukazaki T., Ishitani R., Suga H., Nureki O., Nature, 496, 247-251 (2013).

19) Hipolito C. J., Bashiruddin N. K., Suga H., Curr. Opin. Struct. Biol., 26, 24-31 (2014) .

20) Kodan A., Yamaguchi T., Nakatsu T., Sakiyama K., Hipolito C. J., Fujioka A., Hirokane R., Ikeguchi K., Watanabe B., Hiratake J., Kimura Y., Suga H., Ueda K., Kato H., Proc. Natl. Acad. Sci. USA, 111, 4049-4054 (2014).

21) Dawson R. J., Locher K. P., Nature, 443, 180-185 (2006).

22) Ito K., Sakai K., Suzuki Y., Ozawa N., Hatta T., Natsume T., Matsumoto K., Suga H., Nat. Commun., 6, 6373 (2015). 